\title{
Granger Causality Analysis of Profitability and Efficiency in Ukrainian Banking Sector
}

\author{
Bohdan Kyshakevych \\ Department of economics and \\ management \\ Drohobych Ivan Franko State \\ Pedagogical University \\ Drohobych, Ukraine \\ and Polonia Academy \\ Czestochowa, Poland \\ https://orcid.org/0000-0001-5721-8543
}

\author{
Anatolij Prykarpatsky \\ Institute of Mathematics \\ Cracow University of Technology \\ Cracow, Poland \\ https://orcid.org/0000-0001-5124-5890
}

\author{
Dmytro Mazharov \\ Department of economics and \\ management \\ Drohobych Ivan Franko State \\ Pedagogical University \\ Drohobych, Ukraine
}

https://orcid.org/0000-0002-9640-491X

\begin{abstract}
The paper aims to evaluate the relationship between profitability and efficiency in the Ukrainian banking sector during the period 2008-2017 using Granger causality test. Profitability was estimated by means of two ratios, namely ROA (Return on Assets) and ROE (Return on Equity). For estimation of bank efficiency we used input- and outputoriented technical efficiency measures according to Constant returns to scale (CRS) and Variable returns to scale (VRS) framework in the Data Envelopment Analysis. The usage of VRS approach allowed us additionally to calculate scale efficiency for all banks. Besides, we evaluated the operational efficiency of the banks on the basis of cost-to-income ratio (CIR). We calculated relationship between profitability and efficiency using Granger causality test and correlation coefficient. Of all the pairs of variables that represent profitability and efficiency, the existence of two-sided Granger causality was confirmed only between ROE and the scale efficiency in the DEA-output oriented model. One-way causality was detected between the pair of variables CRS $\rightarrow$ ROE and ROA $\rightarrow$ CIR. Interestingly, causality is not detected between all measures of DEA efficiency, whereas the operational effectiveness of CIR has shown a bi-directional causality with VRS -input and -output efficiency measures.
\end{abstract}

Keywords-profitability, efficiency, DEA analyze, Granger test, causality, operational efficiency, bank

\section{INTRODUCTION}

Information concerning the trend towards efficiency and profitability plays a crucial role in the formulation of strategy to enhance the performance of the banking business. Recognition of causality directions between profitability and efficiency of the bank is very important and goes beyond the interest from academia and theoretical science, since it has many empirical consequences.

Unfortunately, the well-known terms efficiency, profitability and productivity even in scientific literature are very often used incorrectly. In fact, there are several quite substantial differences between those notions. First of all, profitability represents the rate of return a bank has been able to generate from using the resources in order to produce and sell services in order to generate profit. Profitability deals with the analysis of relationship between incomes and expenses and on determination of the level of generated profits in comparison to the size of assets, equity or attracted investments. Then efficiency measures the ability to achieve the desired effects or results with minimal waste of time, effort or skill and deals with the analysis of the relationship between input and output factors.

Besides, both efficiency and profitability present different approaches and concepts from methodological point of view. Stavárek D. and Polouček S. [1] note that profitability and efficiency can be characterized as performance indicators of a single unit calculated without the need for benchmarks. On the other hand, many methods of efficiency estimation are based on relativity and can only be calculated with respect to some benchmark

Relationship between efficiency and profitability of banks and other financial institutions are quite a popular topic for discussion and analysis in economic literature. Kosmidou et al in [2] conducted a study of key factors affecting the profitability and efficiency of UK banks and the relationship between them. It was noted that the efficiency of British banks, measured by the coefficient of CIR (cost to income ratio) showed a tight negative correlation with the profitability of banks.

An analysis of the relationship between the profitability and efficiency of Indian banks was conducted by Kumar [3]. Based on the data on the activities of 27 banks in 2005 Kumar analyzed the relationship between technical efficiency (TE) and profitability in the industrial banking sector in India. The Data Envelopment Analysis (DEA) method was used to determine the technical efficiency.

Werner and Moormann [4] investigated the empirical relationship between the efficiency and profitability of the five major economies of the European Union from the position of the corporate bank strategy for the period 19982005. The results of statistical and regression analyses show that profitable banks operate with higher technical efficiency than their competitors. In addition, the strategic environment and, consequently, the structure and concentration of the national financial sector have a significant impact on the financial performance of the bank.

The study of the relationship between efficiency and profitability by means of applying a new performance decomposition model was performed by Keramidou et al. [5]. This method is suitable for making consistent inferences about the performance of a two-stage production system, as well as the main sources of inefficiencies within the system. 
Loukoianova analyzed the efficiency and profitability of Japanese banks from 2000-2006 in research [6]. It was used a non-parametric approach and the data envelopment analysis (DEA) to analyze the banks' cost and revenue efficiency. The results show that although Japanese bank profitability during analyzed period was low in comparison to that in the majority of advanced countries, there was considerable potential for efficiency growth, especially through increased cost-sharing arrangements among regional banks.

Mykhayliv [7] reviews the performance of social banks in terms of the bank business model, economic efficiency, asset quality and stability by comparing social banks with the thirty global systemically important banks (G-SIBs) of the Financial Stability Board over the period 2000-2014. It was indicated that social banks are relatively more economically efficient than the G-SIBs, however, cost to income ratio is insignificant in all regressions.

Palečková [8] calculated relationship between profitability and efficiency in the Czech banking sector during the period $2004-2014$ using Granger causality and correlation coefficient. However, this paper does not confirm the causality between profitability and efficiency while relationship on the basis of correlation coefficient is recognized.

Using Granger-type causality test estimations Casua and Girardone [9] investigated the relationship between competition and efficiency. Results show that the main EU banking markets before the 2008-2009 crises had become progressively more concentrated and less cost efficient.

Andersson et al. [10] used a data set covering the period 1997-2008 and applied Granger causality tests to estimate the finance-growth relationship for state-owned commercial banks (SOCBs), joint stock commercial banks (JSCBs) and rural credit cooperatives (RCCs). Their results showed that SOCBs and RCCs do not Granger-cause GDP growth and that SOCBs even have a negative effect on manufacturing growth, whereas PBs and JSCBs support economic growth.

Today, the problems of profitability and efficiency forecasting for Ukrainian banks has become extremely important taking into account very rigorous conditions in which Ukrainian banks are currently operating. Since 2014, the Ukrainian government has declared more than 90 banks insolvent. In December 2016 the government was forced to nationalize even PrivatBank - the biggest Ukrainian bank that constitutes approximately 20 percent of the Ukrainian banking sector. After nationalization of PrivatBank, the regulator discovered a hole in its ledger of 148 billion UAH (roughly $\$ 5.3$ billion).

In recent years, as a result of the crisis in the financial and stock markets, domestic commercial banks have been forced to work in conditions of significant outflow of client funds, limiting access to international capital markets, falling stock prices and a record increase in problem loans that require adequate collateral. According to the NBU, the fact that Ukraine's banking system in 2017 set a world record for the size of problem loans, which was then almost one trillion UAH, speaks of a deep crisis in which the Ukrainian banking sector found itself. The increase in the amount of toxic assets and non-performing loans NPL was influenced by the banks' implementation of updated credit risk assessment requirements in accordance with the $351^{\text {st }}$ Resolution of the National Bank of Ukraine, which resulted in a sharp increase in the share of problem loans from $31 \%$ at the end of 2016 to $57 \%$ in the spring of 2017.

Analyzing 2017 it should be noted that the operating income of the sector increased by $10 \%$ for the year but administrative expenses grew faster, which resulted in an increase in operating profit of only $8 \%$ or 40.7 billion UAH. Due to the significant amount of deductions to reserves because of the high level of NPL, the banking system finished the year with a loss of 24.4 billion UAH, which was formed mainly by Privatbank and two banks with stateowned Russian capital. The positive fact is that the number of loss-making banks has decreased from 33 in 2016 to 18 in 2017, and those with an operating loss - from 23 to 14 .

All this emphasizes the importance of improving the quality of crisis situation forecasts in the Ukrainian bank business and the need to establish the nature of the relationship between such key concepts as profitability and efficiency. The purpose of the paper is to analyze the relationship between profitability and efficiency in the Ukrainian banking sector during the period from 2008 to 2017.

\section{METHODOLOGY AND DATA USED}

\section{A. Granger causality}

In statistics, the dependence is any statistic relation (causal or not) between two random variables or bivariate data. Causal relation (causality) is the connection between phenomena, in which one phenomenon, which is called the cause, in the presence of certain conditions generates another phenomenon - a consequence. The most common concepts for determining the nature of the relationship between events is correlation and causality. For the most part, the correlation takes place when two quantities are linear in relation to each other. Correlation is a statistical measure that describes the size and direction of a relationship between two or more variables. A correlation between variables, however, does not automatically imply that the change in one variable is the cause of the change in the other variable.

Causation indicates that one event is the result of the occurrence of the other event, or in other words exist a causal relationship between the two events or variables. Very often it is also referred to as cause and effect. Theoretically, the difference between the two types of relationships is easy to identify - an action or occurrence can cause another, or it can correlate with another. In reality, unfortunately, it is much more difficult to correctly determine cause and effect in comparison to establishing correlation.

An existence of a correlation between variables does not always mean causality; therefore, for the purpose of identifying causality between efficiency and profitability, we used the Granger causality test.

The essence of the Granger test is that variable $x$ is causal relative to variable $y$ if changes in $x$ are preceded by changes in $y$, and not vice versa. Consequently, the simultaneous fulfillment of the following conditions is necessary: variable $x$ makes a significant contribution to the prediction of 
variable $y$, while variable $y$ does not make a significant contribution to the prediction of variable $x$.

\section{B. Profitability measures}

The key point in determining the nature of the relationship between profitability and the efficiency of banks is the choice of indicators that can be used to evaluate them in the best way. The analysis of scientific literature on this topic shows that most researchers (for example T. Beck et al. [12]) calculate profitability based on the ROA and ROE ratios. In some studies (e.g. Dima et al. [13] and Houston et al. [14]) for this purpose the net interest margin NIM is used very often.

In the role of indicators that characterize profitability we used return on assets ROA and return on equity ROE ratios. The ROA (return on assets ratio) is calculated by dividing net income by average total assets. The large value of ROA indicates effective and balanced management of the bank's assets, but it may also be a consequence of the high level of riskiness of the bank's portfolio. The reasons for low profitability of ROA may be a small proportion of working assets. As for Ukraine the best value is considered at the level of $1 \%$. When calculating the ROA the following aspects should be taken into account:

- The amount of assets can fluctuate significantly during the year, so it is advisable to take into account the value of this indicator at the end of the quarter, month, or week.

- Some authors note that the negative value of profitability does not make sense, and in this case, the profitability should be equated to zero and the indicators of loss calculated separately. In our opinion, this approach is not correct, because there is a concept of negative profitability.

Dynamics of ROA for the entire banking system of Ukraine for the period from 2008 to 2017 is presented in the Figure 1.

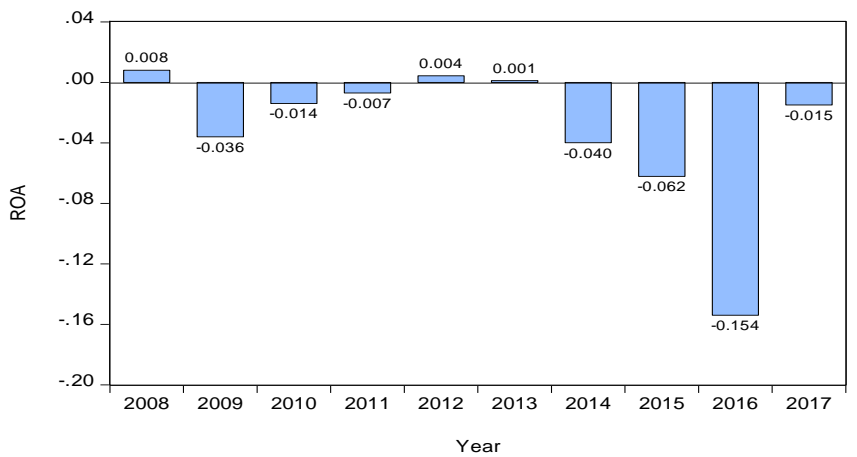

Fig. 1. Dynamics of ROA for the entire banking system of Ukraine for the period from 2008 to 2017. (Source: author's calculations on the base of [14])

ROE is a measure of the bank management ability to generate income from the existing equity. ROE is equal to a fiscal year net income, divided by total equity. The optimal ROE value should be at least $15 \%$. The ratio of profit and equity characterizes the stability of the banking institution. Calculating the ROE for different periods helps to understand the changes in the banks' profitability trend. The tendency towards a stable growth of the return on equity ratio means the bank's ability to generate profit to shareholders. Dynamics of ROE for the entire banking system of Ukraine for the period from 2008 to 2017 is presented in Figure 2.

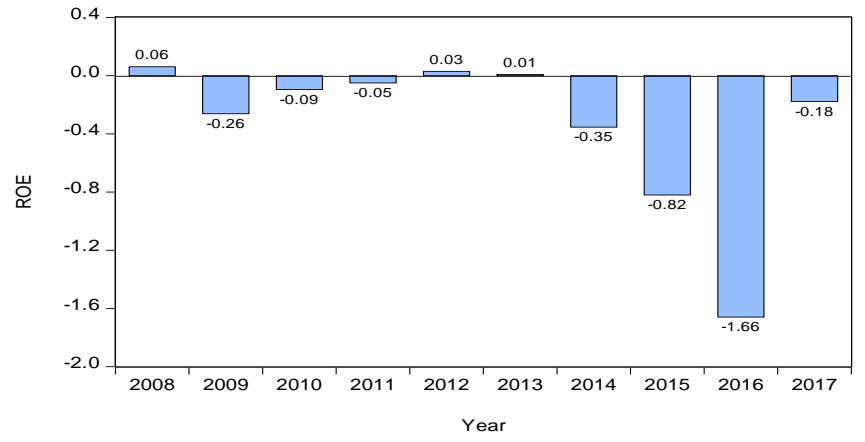

Fig. 2. Dynamics of ROE for the entire banking system of Ukraine for the period from 2008 to 2017 (Source: author's calculations on the base of [14])

\section{Efficiency measures}

We determined efficiency on the basis of the DEAapproach and bank's CIR ratio. In order to assess DEAefficiency, we selected an intermediary approach with the following inputs: interest expense, fixed assets and intangible assets, commission, administrative and operating expenses, and loanable funds and outputs: loans and other assets (see Table I).

TABLE I. INPUTS AND OUTPUTS OF THE DEA MODEL

\begin{tabular}{|l|l|}
\hline \multicolumn{1}{|c|}{ Inputs } & \multicolumn{1}{c|}{ Outputs } \\
\hline Interest expense & Loans \\
Fixed assets and intangible assets & Other assets \\
$\begin{array}{l}\text { Commission, administrative and operating } \\
\text { expenses }\end{array}$ & \\
Loanable fund &
\end{tabular}

To assess the efficiency of banks on the basis of DEAanalysis we used both an input and output-oriented DEA models with variable (VRS) and constant (CRS) scale effects that made it possible to further assess the scale efficiency SE of Ukrainian banks.

CIR (cost to income ratio) is very popular financial ratio in bank analysis. This ratio can be calculated as the ratio of banks' operating costs to operating income:

$$
C I R=\frac{\text { bank' s operating costs }}{\text { bank' s operating income }}
$$

With regard to the assessment of the CIR ratio, it should be noted that bank itself often changes its approach to calculating this coefficient, for example, when deciding whether to include or not include in the formula a particular type of operating expenses or revenues. Operational income - income received by the bank as a result of operations or services delivery to its clients. Operating income includes interest (interest received) and non-interest income from trading operations in the foreign exchange market and securities market, dividends, income from financial leasing, received fines and so on. Typically, operating income does not include income derived from the sale of fixed assets, 
income of non-operating units, fines and penalties. In international practice, dividends received from investments in subsidiaries and income from operating lease of fixed assets and intangible assets are not added to operating income.

Sometimes incomes and expenses associated with the formation of reserves can either be included into the formula for CIR calculating or not. In fact, this is the main reason that hinders the objective comparison of banks on the basis of CIR.

However, with the use of a unified approach to all banks, as it was done in this article, CIR can become a flexible and rather informative measure of the bank's performance and the measure that makes banks comparison possible. Dynamics of CIR for the entire banking system of Ukraine is presented in Figure 4.

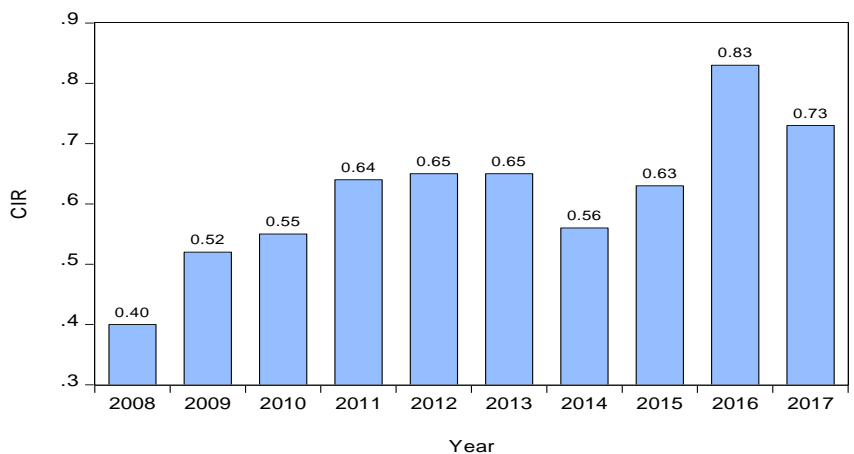

Fig. 3. Dynamics of the CIR for Ukrainian banking system for the period from 2008 to 2017 (Source: author's calculations on the base of [14])

All bank-level data used for calculation of CIR, ROA, ROE and DEA based efficiencies are obtained from the official site of National Bank of Ukraine and are reported in UAH.

\section{RESULTS}

\section{A. Correlations between efficiency and profitability variables}

For the numerical realization of the DEA analysis, namely, the estimation of VRS and CRS efficiencies, we used the EMS (Efficiency Measurement System, Version 1.3) program. A statistical sample of CIR, ROA, ROE, input oriented VRS, CRS, and SE measures (VRSI, CRS and SEI respectively) and output-oriented VRS and SE efficiency measures (VRSO and SEO respectively) was generated in the form of panel data for the twenty largest Ukrainian banks for the period from 2008 to 2017. It is well known in the literature related to Data Envelopment Analysis (DEA) that when we deal with constant returns to scale (CRS), then input- and output oriented radial measures of technical efficiency are identical.

The input- and output-oriented technical efficiency measures will, in general, differ in case of variable returns to scale (VRS) framework. Therefore, we only used inputoriented CRS. Statistical analysis of panel data and all tests implemented in the article were conducted using the program EViews 10. Descriptive statistics for the analyzed period of all variables that determine the efficiency and profitability of Ukrainian banks are given in Table II.
TABLE II. DESCRIPTIVE STATISTICS

\begin{tabular}{|l|l|l|l|l|l|}
\hline & Mean & Median & Maximum & Minimum & Standard \\
\hline CIR & 67.49 & 54.35 & 819.10 & 7.83 & 74.97 \\
\hline CRS & 44.74 & 40.66 & 100.00 & 15.11 & 20.69 \\
\hline ROA & -1.97 & 0.24 & 13.08 & -75.48 & 9.76 \\
\hline ROE & - & 2.57 & 888.89 & -4627.30 & 359.04 \\
\hline SEI & 61.26 & 55.74 & 100.00 & 21.07 & 23.90 \\
\hline SEO & 56.13 & 51.41 & 100.00 & 21.07 & 21.08 \\
\hline VRSI & 77.07 & 83.70 & 100.00 & 15.36 & 24.30 \\
\hline VRSO & 80.81 & 85.95 & 100.00 & 32.30 & 20.14 \\
\hline
\end{tabular}

(Source: author's calculations)

On the basis of the CIR, ROA, ROE and CRS ratios analysis of the twenty largest Ukrainian banks for the period from 2008 to 2017, we can note that the domestic banking sector has experienced two major crises during this time: during 2008-2009 and during 2014-2016 which was much more powerful having been provoked by the war in the East, serious economic problems that had been accumulated by that time and were provoked by external factors such as the aggressive foreign economic policy of Russia and internal ones - the high level of corruption of the power of that time. It resulted in capital outflow from the financial system of the country and the collapse of almost a hundred banks. There is no doubt that the presence of such a significant volatility of the main indicators of banking institutions activity significantly complicates the statistical analysis and forecasting of banking business in Ukraine, but finding causal links between these indicators would make it easier for the management of the bank to form a more flexible system of risk management and risk assessment in order to prevent such crises.

As evidenced from Table III, which shows correlations between all the analyzed performance and profitability of banks, ROA and the CIR correlate most closely with each other (correlation coefficient equal to -0.42), with a slightly lower correlation coefficient of 0.31 between ROA and CRS. However, the correlation between the two variables does not mean that there are causal relationships between them.

TABLE III. CORRELATION BETWEEN INDICATORS OF EFFICIENCY AND PROFITABILITY

\begin{tabular}{|c|c|c|c|c|c|c|}
\hline & CIR & CRS & SEI & SEO & VRSI & VRSO \\
\hline ROA & -0.42 & 0.31 & 0.16 & 0.23 & 0.16 & 0.16 \\
\hline ROE & -0.11 & 0.09 & 0.05 & 0.06 & 0.05 & 0.06 \\
\hline
\end{tabular}

\section{B. Granger causal relationship}

In order to determine whether $x$ is the cause of $y$, it is necessary to determine which portion of the variance of the current value $y$ can be explained by the past values of variable $y$ itself and whether the addition of past values of variable $x$ can increase the portion of the explained variance. In a regression analysis, variable $x$ will be the cause of $y$ if the corresponding coefficients in the lags $x$ are statistically significant. Thus, variable $x$ will not be casual for variable $y$, if the excluding from the model the information about the past values of variable $x$ does not worsen the predicted value $y$. In other words Granger's causation means that knowledge of the past values of one variable $x$ helps to improve the predictions of another variable $y$. 
For example, if Granger's causality is determined between operational efficiency $\mathrm{C} I R_{\mathrm{lt}}$ of 1-th bank in year $\mathrm{t}$ and the corresponding return on capital $R O E_{l t}$, then the key equations in the Granger's test will look like:

$$
\begin{gathered}
\mathrm{CIR}_{l t}=\sum_{i=1}^{n} a_{i}^{\mathrm{CIR}} \mathrm{CIR}_{l t-i}+\sum_{j=1}^{n} b_{j}^{\mathrm{CIR}} \mathrm{ROE}_{l t-j}+u_{l t}^{\mathrm{CIR}} \\
\mathrm{ROE}_{l t}=\sum_{i=1}^{n} c_{i}^{\mathrm{ROE}} \mathrm{ROE}_{l t-i}+\sum_{j=1}^{n} d_{j}^{\mathrm{ROE}} \mathrm{CIR}_{l t-j}+u_{l t}^{\mathrm{ROE}}
\end{gathered}
$$

Based on the least squares method to equations (2) and (3) we can formulate four different hypotheses about the relationship between operational efficiency and return on capital:

One-direction Granger's causality from CIR to ROE. In this case, operational efficiency CIR improves the forecast of return on capital ROE, but not vice versa. Hence, $\left(\sum_{i=1}^{n} d_{j}^{R O E} \neq 0\right)$ and $\left(\sum_{i=1}^{n} b_{i}^{C I R}=0\right)$.

One-direction Granger's causality from ROE to CIR. In this case, ROE improves the forecast of CIR, but not vice versa. Hence, $\left(\sum_{i=1}^{n} d_{j}^{R O E}=0\right)$ and $\left(\sum_{i=1}^{n} b_{i}^{C l R} \neq 0\right)$.

Bi-directional Granger's causality. In this case ROE improves the forecast of operational efficiency CIR and vice versa. Hence, $\left(\sum_{i=1}^{n} d_{j}^{R O E} \neq 0\right)$ and $\left(\sum_{i=1}^{n} b_{i}^{C I R} \neq 0\right)$.

Independence between CIR and ROE. In this case there is no Granger's causality in any direction. Hence, $\left(\sum_{i=1}^{n} d_{j}^{R O E}=0\right)$ and $\left(\sum_{i=1}^{n} b_{i}^{C I R}=0\right)$

It is obvious that Granger's causality is a necessary but not sufficient condition for causation. The main idea of the Granger test was that the future cannot be the cause of the present or the past. That is, the reason, at least, must precede the result. However, the very fact of the precedence does not guarantee the existence of a causal relationship. It is important that the preliminary values of "causes" made a tangible impact on the future values of the "consequence" and, moreover, the past values of the "consequence" did not have a significant effect on the future values of "causes".

Since the Granger causality test is usually applied to stationary series, we used the Levin-Lin-Chu unit-root test on the existence of single roots separately for each of the variables CIR, ROA, ROE, CRS, VRSI, VRSO, SEI and SEO. The test results, which were obtained using the Eviews package, indicate that there are no reasons for confirming the null hypothesis of the existence of single roots, and, consequently, our time series can be considered stationary on the $5 \%$ confidence interval.

Given that the Granger causality test is very sensitive to the length of lag, as many authors point out, we used the Akaike (AIC) and Schwarz (SC) information criteria in order to find the most appropriate size of lag $n$. The results of these criteria calculation for evaluating the quality of parameters selection are given in Table IV.

TABLE IV. CRITERIA FOR CHOOSING THE OPTIMAL LAG LENGTH

\begin{tabular}{|c|c|c|c|c|c|c|}
\hline Lag & LogL & LR & FPE & AIC & SC & HQ \\
\hline 0 & -1773.7 & NA & 64.8 & 29.7 & 30.1 & 29.8 \\
\hline 1 & -1592.5 & 332.2 & 12.8 & 28.1 & 32.0 & 28.9 \\
\hline 2 & -1513.1 & 133.7 & 12.2 & 28.0 & 29.9 & 29.7 \\
\hline 3 & -1440.0 & 112.1 & 15.5 & 28.2 & 34.1 & 30.6 \\
\hline 4 & -1362.5 & 107.2 & 18.3 & 28.3 & 36.0 & 31.4 \\
\hline
\end{tabular}

where

LR: sequential modified LR test statistic (at 5\% level).

FPE: final prediction error.

AIC: Akaike information criterion.

SC: Schwarz information criterion.

HQ: Hannan-Quinn information criterion.

It is easy to see from Table 8 that the criteria Akaike (AIC), Schwartz (SC) and FRE recommend for these autoregressive models lag 2. According to the results of Granger's causality test obtained by means of EViews 10, a system of causal relationships between all the analyzed variables was then built (see Figure 4).

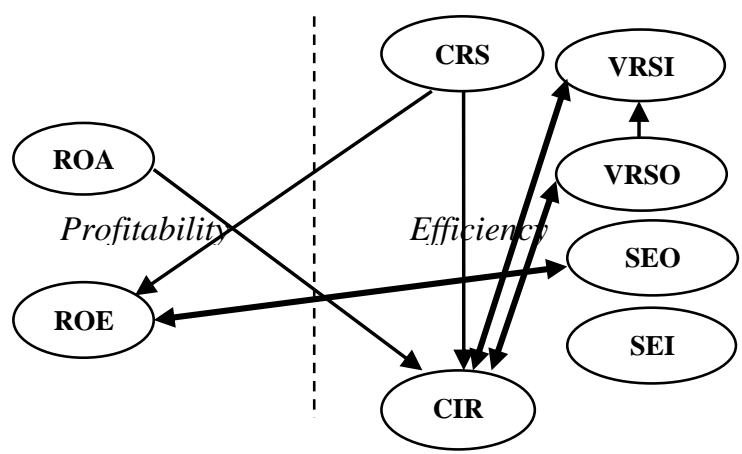

Fig. 4. The scheme of causal relationships between efficiency and profitability indicators of Ukrainian banking activities. (Source: author's calculations)

If we only take into account the relationship between profitability and efficiency, then we have to admit existence of the bi-directional Granger causality between ROE and SEO. One-directional causality was revealed between such pairs of variables as $\mathrm{CRS} \rightarrow \mathrm{ROE}$ and ROA $\rightarrow$ CIR. In the first position in pairs there are variables that are causal in relation to the second variable. It is easy to see that, unlike ROA, return on equity ROE of the largest Ukrainian banks is more sensitive to efficiency-based DEA-analysis during previous periods of time. On the one hand, this result looks rather unexpected, since in the role of outputs variables for DEA model, we took the assets of banks that should which should lead to a closer relationship between ROA and DEAefficiency. The lack of such a relationship can be explained by the fact that DEA analysis only provides comparative banking performance and today, in a situation where Ukrainian banks have extremely problematic asset portfolios and recently demonstrated loss-making activity, it is quite natural that the DEA measures do not reveal a cause-andeffect relationship with the ROA.

A slightly different situation arises if the efficiency is evaluated using the CIR coefficient, which is determined for 
each bank individually. In this case, not only the return on assets ROA, but all of the DEA-efficiency indicators, besides indicators of scale efficiency, will be causative in relation to the CIR. In general, of all efficiency and profitability indicators of banking activity, the CIR ratio most often acts as a consequence or cause in Granger's causality tests. Moreover, between CIR and VRS (Variable Returns to Scale) efficiency, calculated on the basis of the BCC model or the VRS boundary for both the input- and output-oriented models, there exists bi-directional Granger's causality. In this case operational efficiency CIR improves the VRS efficiency forecast and vice versa.

Interestingly, in spite of the existence of a severe causation relationship between ROA and CIR, the correlation between these indicators is moderate (equal to -0.42) and even less than the correlation between the variables ROA and ROE, which is 0.5 . The significant difference between correlation and causation also suggests that the existence of a correlation between the ROA and ROE ratios in our case does not guarantee the existence of a causal relationship between them. Thus, the research carried out in the study of the relationship between profitability and efficiency of Ukrainian banks has confirmed that the presence of correlation between them does not always mean the presence of the effect of causality.

This can be explained by the fact that the correlation between the two phenomena means that if we began to fix one of them more often, we also note the frequency change with which we meet the second one. Cause-and-effect relationships are much more complicated. Thus, if we mark the simultaneous change of two quantitative indicators and assume that one of them has become the cause of the second, this assumption may turn out to be false.

A similar result was obtained by Paleckova [8] for the Czech banking system, where, based on Granger's causality test, the existence of the relationship between profitability and bank efficiency over the period from 2014 to 2014 was also investigated. In this study, ROE was found to be a causal variable for efficiency, which was determined on the basis of DEA models, and the opposite assertion was incorrect - efficiency was not a causal variable for DEA efficiency. In addition, the correlation between the variables ROE and ROE was very small. The causation was not found for all the other variables that participated in the study and presented the profitability and effectiveness of the Czech banks.

\section{CONCLUSIONS}

The relationship between efficiency and profitability has been a much debated topic in recent years. This paper has tried to assess the possibility that one of the two variables representing either efficiency or profitability could cause (in a Granger's sense) the other. Efficiency was estimated by means of DEA approach and coefficient CIR (cost to income ratio), while profitability was measured by return on assets ROA and return on equity ROE.

The analysis showed that the bank efficiency for previous periods of time obtained on the basis of DEA models has a significant impact on the ROE prediction, unlike the return on assets ROA. Of all the pairs of variables that characterize profitability and efficiency, the existence of bi-directional
Granger causality was revealed only between ROE and the scale efficiency SEO in the DEA output-oriented model. One-directional causality was found between such pairs of variables as $\mathrm{CRS} \rightarrow \mathrm{ROE}$ and $\mathrm{ROA} \rightarrow \mathrm{CIR}$.

Interesting is the fact that causality is practically not detected between the very measures of DEA efficiency, whereas the operational effectiveness of CIR has shown a bidirectional causality with VRS-input and -output efficiency measures.

In this study, we analyzed relationship between the profitability and the efficiency of Ukrainian banks, and the obtained results confirm that even significant correlation between the variables does not always mean that there is a causal relationship between them.

\section{REFERENCES}

[1] D. Stavárek and S. Polouček."Efficiency and Profitability in the Banking Sector", In: Polouček S. (eds). Reforming the Financial Sector in Central European Countries. Studies in Economic Transition. Palgrave Macmillan, London, pp.74-135, 2004.

[2] K. Kosmidou, S. Tanna, and F.Pasiouras. "Determinants of profitability of domestic UK commercial banks: panel evidence from the period 1995-2002", Economics, finance and accounting applied research working paper series no. RP08 - 4, Coventry: Coventry University, 28 p., 2008.

[3] S. Kumar, "An Analysis of Efficiency-Profitability Relationship in Indian Public Sector Banks", Global Business Review, vol. 9, no. 1, pp. $115-129, \quad 2008 . \quad$ [Online]. Available: https://doi.org/10.1177/097215090700900108. Accessed on: 17 July 2019

[4] K. Werner, and J. Moormann, "Efficiency and profitability of European banks: how important is operational efficiency?," Frankfurt School - Working Paper Series 111, Frankfurt School of Finance and Management, 2009.

[5] I. Keramidou, A. Mimis, A. Fotinopoulou and D. Chrisanthos, "Exploring the relationship between efficiency and profitability", Benchmarking: An International Journal, vol. 20, iss. 5, pp. 647-660, 2013.

[6] E. Loukoianova, "Analysis of the Efficiency and Profitability of the Japanese Banking System", IMF Working Papers, 08/63, 36 p., 2008

[7] D. Mykhayliv, The Economic Efficiency and Profitability of Social Banks, 2016. [Online]. Available: http://hdl.handle.net/10454/11236. Accessed on: 17 July 2019.

[8] I. Paleckova, Relationship between Profitability and Efficiency in the Czech Banking Sector, Silesian University School of Business Administration, Department of Finance and Accounting, 2016, [Online]. Available: http://icfb.rs.opf.slu.cz/sites/icfb.rs.opf.slu.cz/files/paleckova.pdf . Accessed on: 17 July 2019.

[9] B.Casu, and C. Girardone, "Does Competition Lead to Efficiency? The Case of EU Commercial Banks", 2009. [Online]. Available: SSRN: https://ssrn.com/abstract=1200362, Accessed on: January 15.

[10] F. Andersson, K. Burzynska and S. Opper. "Lending for growth? A Granger causality analysis of China's finance-growth nexus", Empirical Economics, November 2016, Volume 51, Issue 3, pp. 897-920, 2016. https://doi.org/10.1007/s00181-015-1034-8

[11] T. Beck, O.D. Jonghe and G. Schepens. "Bank competition and stability: Cross-country heterogeneity", Journal of Financial Intermediation, vol. 22(2), pp. 218-244, 2013.

[12] B. Dima, M.S Dinca and C.Spulbar. "Financial nexus: Efficiency and soundness in banking and capital markets", Journal of International Money and Finance, vol. 47, pp. 100-124, 2014.

[13] J.F. Houston, C. Lin, P. Lin, and Y. Ma. "Creditor rights, information sharing, and bank risk taking", Journal of Financial Economics, vol. 96, pp. 485-512, 2010.

[14] Indicators of the banking system, Official site of the National Bank of Ukraine. [Online]. Available: https://bank.gov.ua/control/uk/publish/article?art id=34661442\&cat_i $\mathrm{d}=34798593$. Accessed on: 17 July 2019. 